\title{
Performance Evaluation of Mini Tractor Operated Rotary Weeder Cum Fertilizer Drill
}

\author{
Regatti Venkat", Pramod Mohnot and Dharmendra \\ Department of Farm Machinery and Power Engineering, CAET, Junagadh Agricultural \\ University, Junagadh, Gujarat, India \\ *Corresponding author
}

\section{A B S T R A C T}

Keywords

Rotary weeder, Fertilizer drill, Calibration, Plant damage, Weeding efficiency

\section{Article Info}

Accepted:

20 August 2020

Available Online:

10 September 2020
Developed rotary weeder cum fertilizer drill was operated by the mini-tractor using threepoint linkage, it performs both the operations of intercultivation and fertilizer application at a time. Experiments were conducted in field by varying forward speed ranged 1.8-2.0 $\mathrm{kmh}^{-1}, 2.5-2.7 \mathrm{kmh}^{-1}$ and $3.0-3.2 \mathrm{~km} \mathrm{~h}^{-1}$. Calibration of the machine was conducted at laboratory condition and at field condition. A $42.67 \%$ more fertilizer was dropped at field calibration on comparing with that of fertilizer dropped at laboratory calibration. The highest effective field capacity of developed machine was found out as $304 \times 10^{-3} \mathrm{hah}^{-1}$ at the forward speed of $3.0-3.2 \mathrm{~km} \mathrm{~h}^{-1}$. The highest field efficiency, highest weeding efficiency and lowest plant damage of developed machine were obtained at $1.8-2.0 \mathrm{~km} \mathrm{~h}^{-}$ ${ }^{1}$ forward speed of operation. The highest field efficiency, highest weeding efficiency and lowest plant damage of developed machine obtained were $86 \%, 91.23 \%$ and $3.62 \%$ respectively. The lowest fuel consumption of developed machine was obtained as $1.30 \mathrm{lh}^{-1}$ at $1.8-2.0 \mathrm{~km} \mathrm{~h}^{-1}$ forward speed.

\section{Introduction}

Weed growth is not stopped at a critical time, it results massive crop loss in crop production. Weeds decrease crop yields from 15 to $50 \%$ depending on the species, density and weeding time through competition with main crop for light, water and nutrition (Hasanuzzaman et al., 2009). Delay in fertilizer application suppresses the crop vegetative development which leads to reduced yield. Research has shown that fertilizer input contributes about $30-50 \%$ of total yield increase for most of the crops
(Stewart et al., 2005). Various methods used to control the weeds are manual weeding, cultural, mechanical, biological and chemical methods. In all these methods the most profitable and friendly is mechanical weeding because it is less polluting the soil and affordable on comparing with other methods.

Different fertilizer application methods are broadcasting, deep placement, foliar spray, fertigation, band placement, pellet application etc. In normal broadcasting and applying fertilizer on surface the nitrogen content in the granular fertilizer may undergoes 
volatilization which leads to loss of fertilizer (Black et al., 1985). It is better to adopt appropriate deep placement method of application to reduce the fertilizer losses. By adopting mechanization in the required areas of agriculture, timely operations with reduced drudgery and cost of cultivation can be achieved. It becomes effective with using rotary weeder combining with fertilizer application unit. To achieve timeliness and effectiveness in both the operations a mini tractor operated rotary weeder cum fertilizer drill was designed and developed. Mini tractor operated rotary weeder cum fertilizer drill was developed for wide spaced crops like castor, cotton and pigeon pea.

\section{Materials and Methods}

Mini tractor operated rotary weeder cum fertilizer drill was designed and developed at the Department of Farm Machinery and Power Engineering, College of Agricultural Engineering and Technology, Junagadh Agricultural University, Junagadh.

The major components of the machine include the frame unit, skid unit, rotary unit with L type blades, reversible shovel furrow openers, power transmission system, fertilizer hopper, Edge cell type metering rotors, fertilizer conveying system and ground wheel. Bevel gears, chains and sprockets were used in power transmission systems. The overall dimensions of the machine length $\times$ width $\times$ height of the machine were $1050 \times 1460 \times$ $1240 \mathrm{~mm}$. The width of coverage of implement was designed for $1.2 \mathrm{~m}$ row crops. Performance of developed machine was evaluated through laboratory experiments and field experiments. The laboratory experiments conducted at the Department of Farm Machinery and Power Engineering. Field experiments conducted at Instructional farm, College of Agricultural Engineering and Technology, JAU, Junagadh.

\section{Laboratory calibration}

Calibration of the machine was donein the laboratory to examine the fertilizer delivery rate by keeping machine stationary.Rotary weeder cum fertilizer drill jacked up, made 20 revolution of ground wheel and fertilizer delivered was measured. Fertilizer dropping rate obtained at different hopper capacities, different ground wheel speeds and different door openings when the machine was stationary. This test repeated for 3 times for each full, $3 / 4,1 / 2$ and $1 / 4$ hopper filling capacities, different speeds of 1.8 to $2.0,2.5$ to 2.7 and 3.0 to $3.2 \mathrm{~km} \mathrm{~h}^{-1}$ and different door openings of $30 \%, 40 \%, 60 \%$ and $100 \%$ of hopper (IS-6316:1993).

\section{Field calibration}

Calibration of machine was also done at field condition to know the variation of fertilizer delivered. During working of the machine fertilizer delivery tubes were removed from the furrow opener boots and separate sacks were held under them to collect the fertilizer.

During field calibration the rate setting which gave recommended dose of fertilizer at the time of laboratory calibration (40\% door opening) was used. It was done by operating the machine, allowing it to complete 20 revolutions ground wheel in field and the amount of fertilizer dropped calculated on hectare basis (i.e. $\mathrm{kgha}^{-1}$ ).

\section{Performance evaluation of mini tractor operated rotary weeder cum fertilizer drill}

Performance evaluation of developed machine was conducted through the two weeding cum fertilizer application operations in the castor field. First weeding operation was done after the 30 days of sowing day and second weeding operation was done after the 45 days of sowing day. During its 
performance evaluation soil parameters, operating parameters and performance parameters was determined.

Performance of the implement evaluated by determining effective field capacity, field efficiency, weeding efficiency, plant damage and fuel consumption.

\section{Experimental design}

The field data were statistically analyzed by using analysis of variance (ANOVA) for Completely Randomized Design (CRD) with six replications. Details of experimental plot are shown in Table 1.

\section{Soil condition}

\section{Soil type}

Castor crop was grown in clay soil which consisted of $42.8 \%$ clay, $35.8 \%$ silt and $20.4 \%$ sand portions.

\section{Soil moisture content (\%)}

Moisture content of the soil determined by standard gravimetric method. Five soil samples taken from the different locations at $10 \mathrm{~cm}$ depth of the test plots in different moisture boxes and kept in oven for 24 hours at the temperature of $105^{\circ} \mathrm{C}$. The mass of wet and dry samples determined and average moisture content on dry basis was calculated (IS: 2720-2-1973).

$$
\text { Moisture Content (d.b.) } \%=\frac{W_{w}-W_{d}}{W_{d}} \times 100
$$

Where;

$\mathrm{W}_{\mathrm{w}}=$ Weight of the wet soil, $\mathrm{g}$ $\mathrm{W}_{\mathrm{d}}=$ Weight of the dry soil, $\mathrm{g}$

\section{Bulk density of soil}

Metallic core cylinder used to collect soil sample from the field. Five samples taken in $100 \mathrm{~mm}$ diameter and $128 \mathrm{~mm}$ long core sampler. The samples weighed with an accuracy of 0.1 gram. The ratio of the dry weight of the soil to the volume gives the bulk density (Punmia et al., 2009).

$$
\begin{aligned}
& \text { Bulk density of soil }(\mathrm{g} / \mathrm{cc})=\frac{\mathrm{Wd}}{\mathrm{V}} \\
& \text { Where, } \\
& \mathrm{W}_{\mathrm{d}}=\text { Weight of the dry soil, } \mathrm{g} \\
& \mathrm{V}=\text { Volume of metallic core, } \mathrm{cm}^{3}
\end{aligned}
$$

\section{Crop condition}

Developed rotary weeder cum fertilizer drill was operated in a castor crop of $120 \times 60 \mathrm{~cm}$ row to row and plant spacing. At the time of first weeding operation the plant height of crop varied from 16 to $24 \mathrm{~cm}$. At the time of second weeding operation the plant height of crop varied from 40 to $53.5 \mathrm{~cm}$.

\section{Measurements of different parameters}

\section{Forward speed}

Performance of mini tractor operated rotary weeder cum fertilizer drill evaluated at three different forward speeds (1.8-2.0, 2.5-2.7 and 3.0-3.2 $\mathrm{kmh}^{-1}$ ).

The forward speed calculated for the mini tractor by observing the time (t) taken to travel $20 \mathrm{~m}$ row length of test plot. The forward speed of operation was calculated by following formula.

$$
\mathrm{s}=\frac{\frac{\pi}{t}}{t}(\mathbf{3})
$$

$\mathrm{S}=$ forward speed of machine, $\mathrm{ms}^{-1}$

$\mathrm{L}=$ distance travelled, $\mathrm{m}$

$\mathrm{t}=$ time taken, $\mathrm{s}$ 


\section{Depth of weeding}

The depth of cut for rotary blade assembly in weeding operation determined by measuring the distance between horizontal soil surfaces to the bottom of dug out pulverized soil with the help of depth gauge.

\section{Depth of fertilizer application}

Depth of fertilizer drilled measured by opening the furrow gently without much disturbing the soil and measured the depth of fertilizer in soil with the help of steel scale.

\section{Wheel slip}

Number of revolutions counted for certain distance of operation for loading and unloading condition. Wheel slippage of mini tractor calculated by using following formula. (IS: 17045-2018).

Percentage of wheel slip $=\frac{(\mathrm{P}-\mathrm{Q})}{\mathrm{P}} \times 100(4)$

Where,

$\mathrm{P}=$ No. of revolution of driving wheels made for a $20 \mathrm{~m}$ distance when the tractor was driven under load,

$\mathrm{Q}=$ No. of revolutions of driving wheels made for a $20 \mathrm{~m}$ distance when tractor was driven without load.

\section{Theoretical field capacity}

It was the rate of area covered without loss of time. It was calculated by using following formula (Kepner et al., 2005).

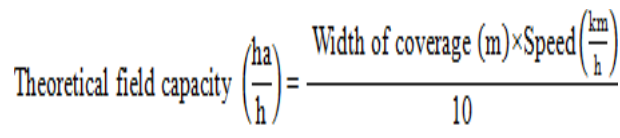

(5)

\section{Effective field capacity}

It was the actual rate of work which includes the time lost in turning at the end of rows and refilling of fertilizer. It was calculated by using following formula (Kepner et al., 2005)

$$
\text { Effective field capacity }\left(\frac{\text { ha }}{\mathrm{h}}\right)=\frac{\text { Width of coverage }(\mathrm{m}) \times \text { Length of strip }(\mathrm{m})}{\text { Time taken }(\mathrm{h}) \times 10,000}
$$

\section{Field efficiency}

Field efficiency defined as the percentage of time the machine operates at its full rated speed and width while in the field. It was calculated by using following formula (Kepner et al., 2005)

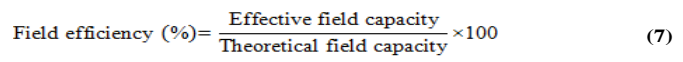

\section{Plant damage}

Number of plants present before the weeding (p) counted in a $10 \mathrm{~m}$ row. After the weeding no. of plants damaged (q) counted for the same row length. Plant damage was calculated with the help of following formula. (Vala et al., 2019)

Plant damage $(\%)=\frac{q}{p} \times 100$

\section{Weeding efficiency}

Weeds present before and after the weeding operation counted to calculate weeding efficiency. Weeding efficiency calculated with the help of following formula. (Rathod $e t$ al., 2010)

Weeding efficiency $(\%)=\frac{X-Y}{x} \times 100(9)$

Where,

$\mathrm{X}=$ No. of weeds before operation per $\mathrm{m}^{2}$ area $\mathrm{Y}=$ No. of weeds after operation per $\mathrm{m}^{2}$ area 


\section{Fuel consumption}

The fuel consumption of mini tractor operated rotary weeder cum fertilizer drill measured as per the standard prescribed method. The auxiliary tank attached at fuel system in between fuel tank and engine. The time of operation by mini tractor and fuel consumed in auxiliary tank were recorded. Fuel consumption of mini tractor was determined by dividing the fuel consumed to the time of operation.

\section{Operational energy for mini tractor} operated rotary weeder cum fertilizer drill

Energy consumption for weeding and fertilizer application calculated by standard energy consumption for tractor in $\mathrm{MJh}^{-1}$. Energy utilized by mini tractor operated rotary weeder evaluated by the following formula (Umar, 2003).

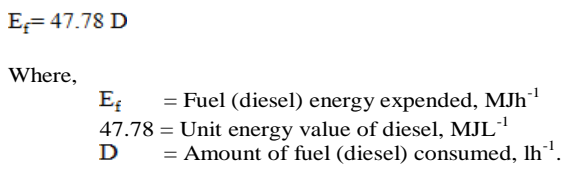

(10)

\section{Results and Discussion}

\section{Laboratory calibration}

Granular urea fertilizer was used in laboratory calibration.

The required fertilizer rate $\left(40 \mathrm{kgha}^{-1}\right)$ noticed at the $40 \%$ door opening of hopper during stationary calibration. The fertilizer rate was adjustable from $29 \mathrm{~kg}$ to $170 \mathrm{~kg}$ per hectare by using this machine. The variation in dropping of fertilizer in between two furrow openers ranged from- $0.54 \%$ to $5.98 \%$.The variation in dropping of fertilizer due to box filling at 1/4, 1/2, 3/4 and full capacity of hopper ranged from $-4.24 \%$ to $4.30 \%$.The variations in quantities of fertilizer dropping due to change in speeds from $1.8-2.0 \mathrm{kmh}^{-1}$ to $3.0-3.2 \mathrm{kmh}^{-1}$ speeds were ranged from -5.56 $\%$ to $5.23 \%$ (Fig. 1-10 and Table 1-10).

\section{Effect of hopper filling and door opening on fertilizer delivery rate}

Fertilizer delivery rate was increased with increased door opening of hopper at all levels of hopper. Fertilizer delivery rate increased from ${ }^{1 / 4}$ capacity of hopper filling to full capacity of hopper filling.

\section{Effect of forward speed of operation on fertilizer delivery rate}

Fertilizer drill was operated at $40 \%$ hopper opening and different speeds by changing the rotational speed of ground wheel to know the variation in fertilizer delivery rates. On increasing the speed of operation, the fertilizer delivery rate was decreased at all levels of hopper. At higher speeds of metering rotor spilling of fertilizer occurs and results less delivery of fertilizer.

\section{Field Calibration}

On increasing the forward speed of operation from $1.8-2.0 \mathrm{kmh}^{-1}$ to $3.0-3.2 \mathrm{kmh}^{-1}$ speed the fertilizer delivery rate was also decreased in field condition. At field condition because of continuous vibrations from the rotary shaft assembly there was a more dropping of fertilizer from hopper to metering mechanism and then to crop through delivery tubes. More fertilizer was dropped at field condition on comparing with that of the fertilizer dropped at laboratory condition by using same rate setting (40\% door opening area of hopper). Variations in fertilizer delivered at field condition and laboratory condition were ranged from $40.66 \%$ to 44.51 . An average variation of $42.67 \%$ was noticed in the study. By using the reduced rate setting (30\% door opening area of hopper) the required fertilizer 
delivery rate $\left(40 \mathrm{kgha}^{-1}\right)$ was obtained at field condition.

\section{Soil moisture content}

At the time of first performance evaluation the average moisture content was found to be $27.56 \%$ on dry basis and at second performance evaluation the average moisture content was found to be $20.86 \%$ on dry basis.

\section{Bulk density of soil}

The bulk density of the soil at the time of first performance evaluation was found to be 1.52 $\mathrm{gcc}^{-1}$ in the test plot and at second performance evaluation the bulk density of $1.46 \mathrm{gcc}^{-1}$ was found in the test plot. Bulk density of soil was decreased by a little amount due to the thorough pulverization at first weeding operation resulted in increased voids in soil.

\section{Depth of weeding}

Depth of cut observed at first weeding was slightly greater than that of second weeding at all the forward speeds during performance evaluation. It was obtained because of more soil moisture content in the field at the time of first weeding operation as compare to the weeding operation.

At higher speeds the depth of cut decreased due to reduced time of contact of blades with the soil in both the weeding operations.

\section{Depth of fertilizer application}

Depth of fertilizer application observed at first weeding and second weeding operations was almost same during performance evaluation. At higher speeds the depth of fertilizer application decreased to little extent at both the weeding operations.

\section{Wheel slip}

At the time of first weeding operation the amount of wheel slip was obtained as -2.53 $\%$. During second weeding operation the amount of wheel slip was obtained as -3.85 $\%$.Wheel slip found at second weeding operation was less than that of first weeding operation because of less moisture content in the field during second weeding operation.

\section{Effect of forward speed on effective field capacity}

Effective field capacity obtained during both the operations increased by increasing the forward speed from $1.8-2.0 \mathrm{kmh}^{-1}$ to $3.0-3.2$ $\mathrm{kmh}^{-1}$. The observations obtained for effective field capacity at the time of first weeding and second weeding were statistically highly significant because by varying the forward speed of operation the effective field capacity also varied widely in the field.

Effective field capacity observed at first weeding operation was slightly greater than that of second weeding operation at all the forward speeds during performance evaluation. It was observed that time losses were more at the time of second weeding operation because of more spread of plants in field.

\section{Effect of forward speed on field efficiency}

During the first weeding operation, the field efficiency was decreased by increasing the forward speed from $1.8-2.0 \mathrm{kmh}^{-1}$ to $3.0-3.2$ $\mathrm{kmh}^{-1}$ speed. At the second weeding operation the field efficiency was slightly varied by changing the forward speed from 1.8-2.0 $\mathrm{kmh}^{-1}$ to $3.0-3.2 \mathrm{kmh}^{-1}$ speed. The measurements obtained for field efficiency for both the weeding operations were statistically non-significant because the time losses obtained for different experiments were not varied much in performance evaluation. 
Table.1 Details of experiment

\begin{tabular}{|c|c|c|c|}
\hline Sr. No. & Variables & Parameter & Levels \\
\hline $\mathbf{1 .}$ & Independent parameters & Forward Speed & $1.8-2.0 \mathrm{~km} \mathrm{~h}^{-1}$ \\
\hline \multirow{2}{*}{$\mathbf{2}$} & & & $2.5-2.7 \mathrm{~km} \mathrm{~h}^{-1}$ \\
\hline & Dependent Parameters & $3.0-3.2 \mathrm{~km} \mathrm{~h}^{-1}$ \\
\cline { 3 - 3 } & & Effective Field Capacity (EFC) \\
\cline { 3 - 4 } & & Field Efficiency (\%) \\
\cline { 3 - 4 } & & Weeding Efficiency (\%) \\
\cline { 3 - 4 } & & Plant Damage (\%) \\
\hline
\end{tabular}

Table.2 Specifications of rotary weeder cum fertilizer drill developed

\begin{tabular}{|c|c|c|}
\hline Sr. No. & Particulars & Details \\
\hline $\mathbf{1}$ & Width of coverage & $1.2 \mathrm{~m}$ \\
\hline $\mathbf{2}$ & No. offurrow openers & 2 \\
\hline $\mathbf{3}$ & Diameter of ground wheel & $0.5 \mathrm{~m}$ \\
\hline $\mathbf{4}$ & Distance covered in 1 revolution of ground wheel & $1.57 \mathrm{~m}$ \\
\hline $\mathbf{5}$ & Area covered in 1 revolution of ground wheel & $1.885 \mathrm{~m}^{2}$ \\
\hline $\mathbf{6}$ & Area covered in 20 revolution of ground wheel & $37.7 \mathrm{~m}^{2}$ \\
\hline $\mathbf{7}$ & No. of revolutions required to cover1 ha area & 5305 \\
\hline
\end{tabular}

Table.3 Effective field capacity obtained during first weeding operation

\begin{tabular}{|l|c|c|c|}
\hline Forward speed, $\mathbf{~ k m ~ h}^{\mathbf{- 1}}$ & $\mathbf{1 . 8 - 2 . 0}$ & $\mathbf{2 . 5 - 2 . 7}$ & $\mathbf{3 . 0 - 3 . 2}$ \\
\hline $\begin{array}{l}\text { Effective field capacity, } \mathbf{1 0}^{-\mathbf{3}} \mathbf{h a h}^{-\mathbf{1}} \text { at } \\
\text { first weeding operation }\end{array}$ & 196 & 258 & 304 \\
\hline
\end{tabular}

$\mathrm{SEm}=0.0059 ; \mathrm{CD}=0.0179$

Table.4 Effective field capacity obtained during second weeding operation

\begin{tabular}{|l|c|c|c|}
\hline Forward speed, $\mathbf{~ k m ~ h}^{-1}$ & $\mathbf{1 . 8 - 2 . 0}$ & $\mathbf{2 . 5 - 2 . 7}$ & $\mathbf{3 . 0 - 3 . 2}$ \\
\hline $\begin{array}{l}\text { Effective field capacity, } \mathbf{1 0}^{-\mathbf{3}} \mathbf{h a h}^{-1} \\
\text { at second weeding operation }\end{array}$ & 187 & 248 & 298 \\
\hline
\end{tabular}

$\mathrm{SEm}=0.0051 ; \mathrm{CD}=0.0153$

Table.5 Field efficiency obtained during first weeding operation

\begin{tabular}{|l|c|c|c|}
\hline Forward speed, $\mathbf{~ k m ~ h}^{-1}$ & $\mathbf{1 . 8 - 2 . 0}$ & $\mathbf{2 . 5 - 2 . 7}$ & $\mathbf{3 . 0 - 3 . 2}$ \\
\hline Field efficiency & 86 & 82.79 & 81.79 \\
\hline
\end{tabular}

$\mathrm{SEm}=1.86 ; \mathrm{CD}=$ non-significant

Table.6 Field efficiency obtained during second weeding operation

\begin{tabular}{|l|c|c|c|}
\hline Forward speed, $\mathbf{~ k m ~ h}^{-1}$ & $\mathbf{1 . 8 - 2 . 0}$ & $\mathbf{2 . 5 - 2 . 7}$ & $\mathbf{3 . 0 - 3 . 2}$ \\
\hline Field efficiency & 82.07 & 79.53 & 80.36 \\
\hline
\end{tabular}

$\mathrm{SEm}=1.54 ; \mathrm{CD}=$ non-significant 
Table.7 Plant damage (\%) at first weeding operation

\begin{tabular}{|l|c|c|c|}
\hline Forward speed, $\mathbf{~ k m ~ h}^{-1}$ & $\mathbf{1 . 8 - 2 . 0}$ & $\mathbf{2 . 5 - 2 . 7}$ & $\mathbf{3 . 0 - 3 . 2}$ \\
\hline Plant damage & 3.62 & 3.6 & 4.66 \\
\hline
\end{tabular}

$\mathrm{SEm}=0.18 ; \mathrm{CD}=$ non-significant

Table.8 Plant damage (\%) at second weeding operation

\begin{tabular}{|c|c|c|c|}
\hline Forward speed, $\mathbf{k m ~ h}^{-\mathbf{1}}$ & $\mathbf{1 . 8 - 2 . 0}$ & $\mathbf{2 . 5 - 2 . 7}$ & $\mathbf{3 . 0 - 3 . 2}$ \\
\hline Plant damage & 4.3 & 4.79 & 7.60 \\
\hline $\mathrm{SEm}=0.16 ; \mathrm{CD}=0.493$ & & &
\end{tabular}

Table.9 Weeding efficiency at first weeding operation

\begin{tabular}{|l|c|c|c|}
\hline Forward speed, $\mathbf{~ k m ~ h}^{\mathbf{- 1}}$ & $\mathbf{1 . 8 - 2 . 0}$ & $\mathbf{2 . 5 - 2 . 7}$ & $\mathbf{3 . 0 - 3 . 2}$ \\
\hline Weeding efficiency & 91.23 & 90.72 & 73.38 \\
\hline
\end{tabular}

$\mathrm{SEm}=0.19 ; \mathrm{CD}=3.58$

Table.10 Weeding efficiency at second weeding operation

\begin{tabular}{|l|c|c|c|}
\hline Forward speed, $\mathbf{~ k m ~ h}^{-1}$ & $\mathbf{1 . 8 - 2 . 0}$ & $\mathbf{2 . 5 - 2 . 7}$ & $\mathbf{3 . 0 - 3 . 2}$ \\
\hline Weeding efficiency & 86.45 & 88.53 & 72.99 \\
\hline
\end{tabular}

$\mathrm{SEm}=2.905 ; \mathrm{CD}=8.76$

Fig.1Graphical representation of fertilizer delivery rate Vs different door openings of hopper

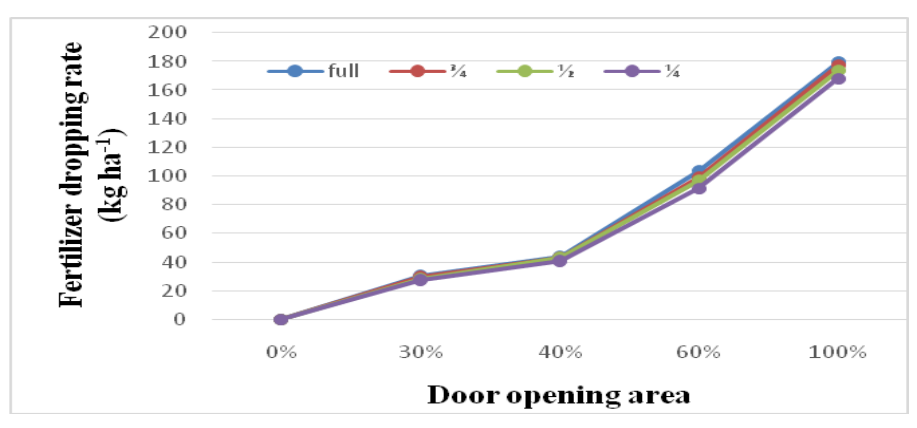

Fig.2 Graphical representation of fertilizer delivery rate at different hopper levels Vs forward speed

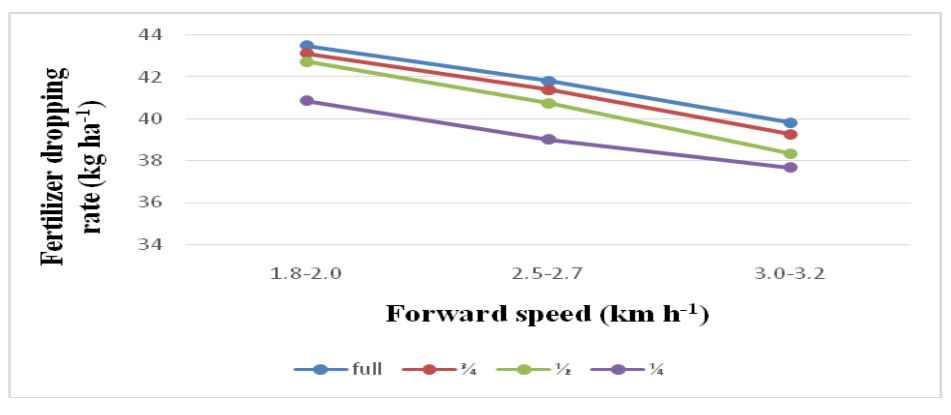


Fig.3 Graphical representation of fertilizer delivery rate Vs forward speed

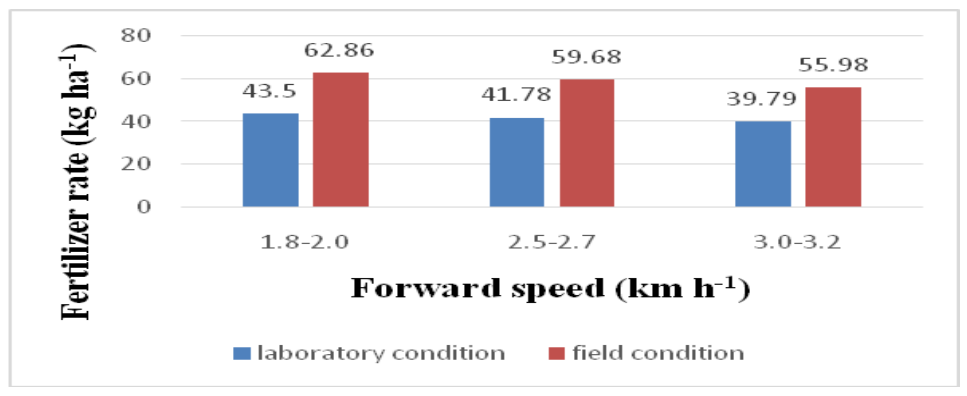

Fig.4 Graphical representation of depth of weeding Vs forward speed

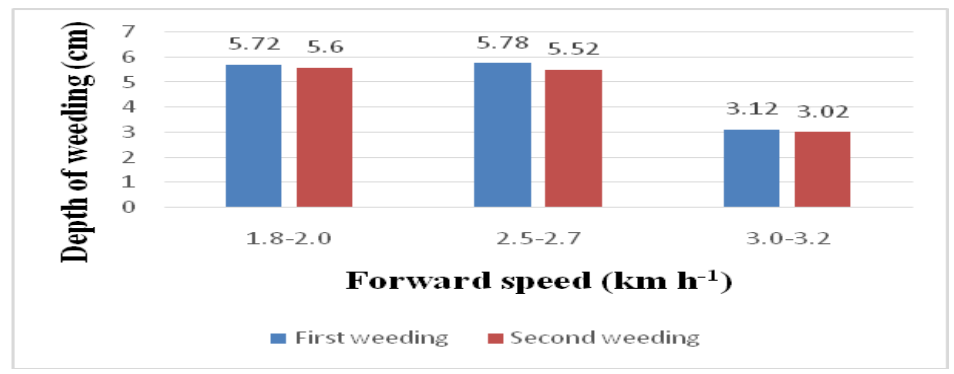

Fig.5 Graphical representation of depth of fertilizer application Vs forward speed

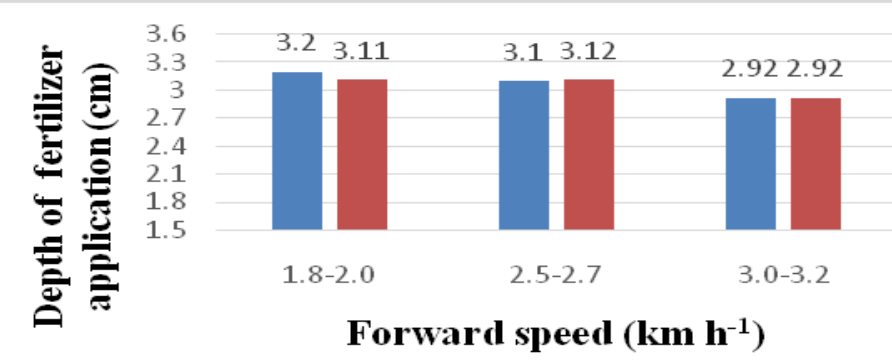

- First weeding Second weeding

Fig.6 Graphical representation of effective field capacity Vs forward speed

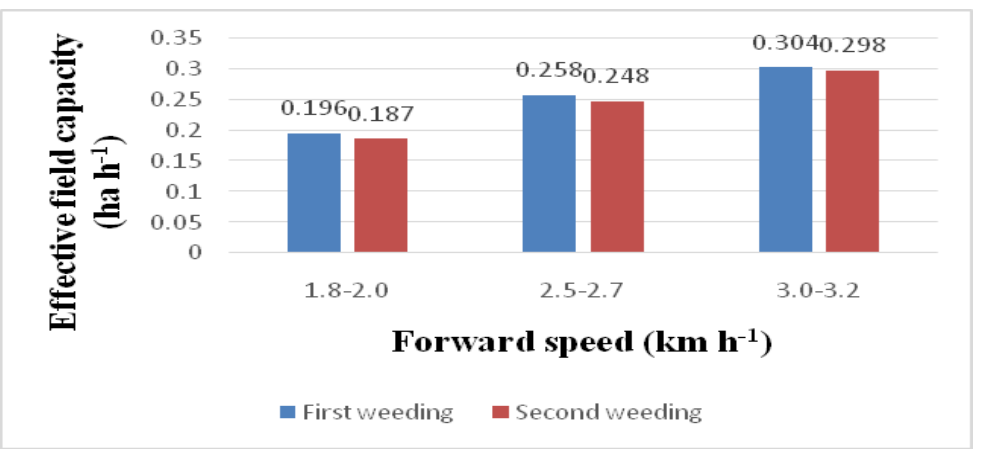


Fig.7 Graphical representation of field efficiency Vs forward speed

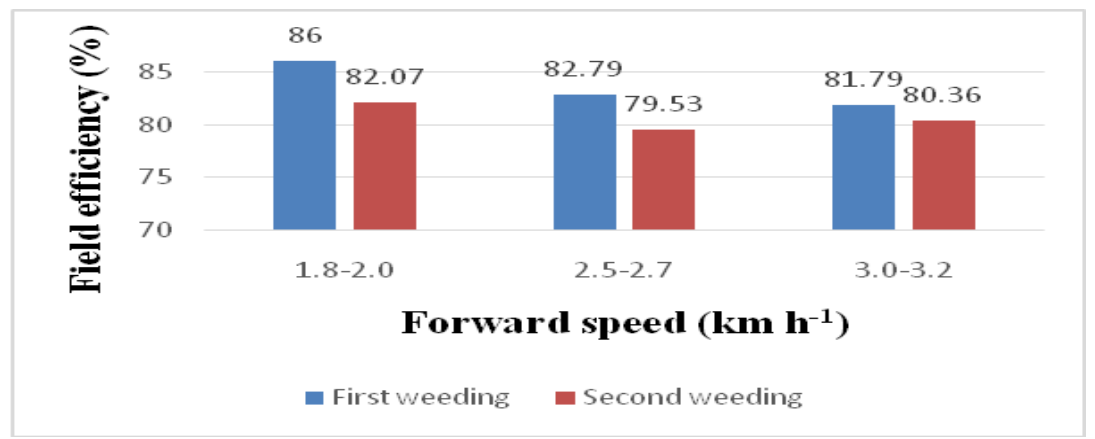

Fig.8 Graphical representation of plant damage Vs forward speed

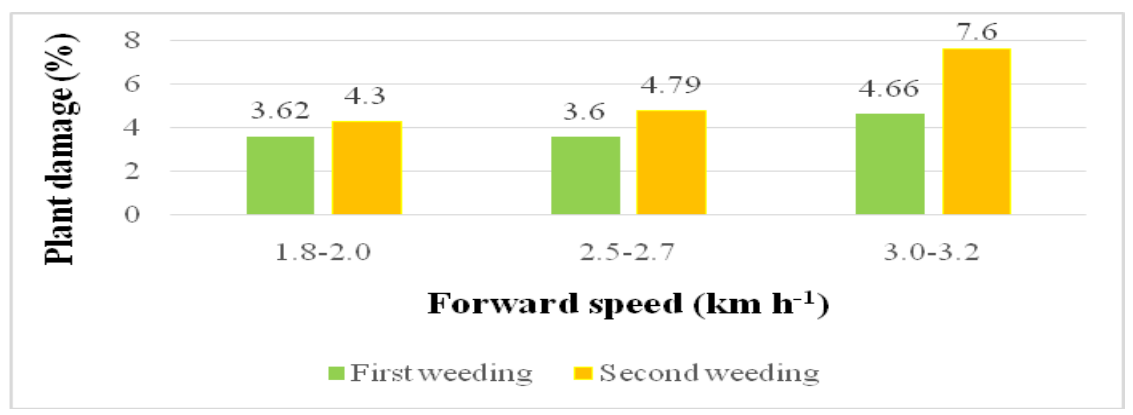

Fig.9 Graphical representation of weeding efficiency Vs forward speed

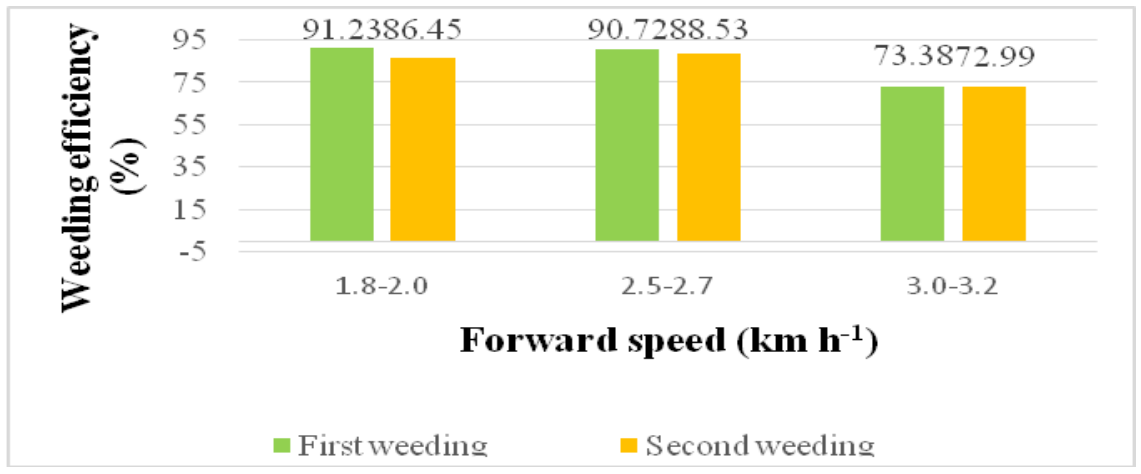

Fig.10 Graphical representation of fuel consumption Vs forward speed

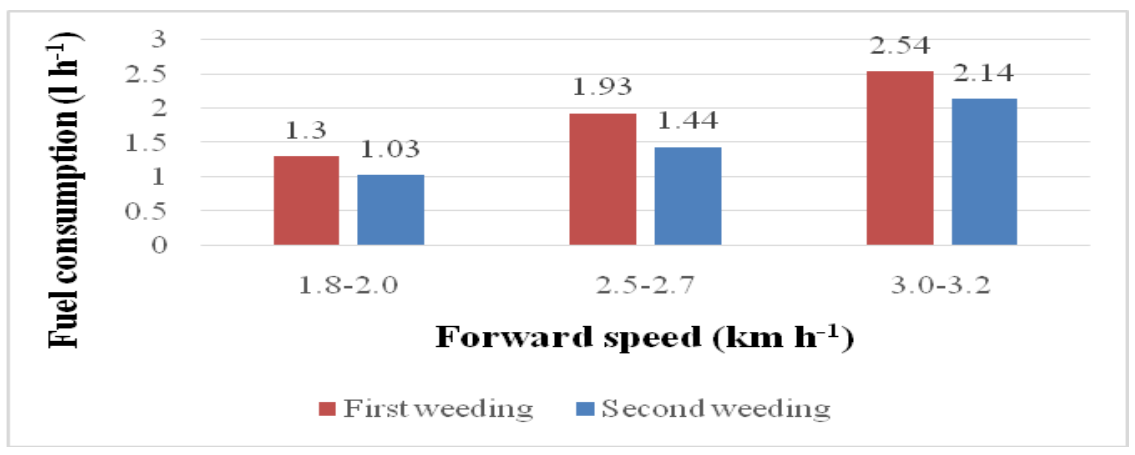


Plate.1 Field Calibration

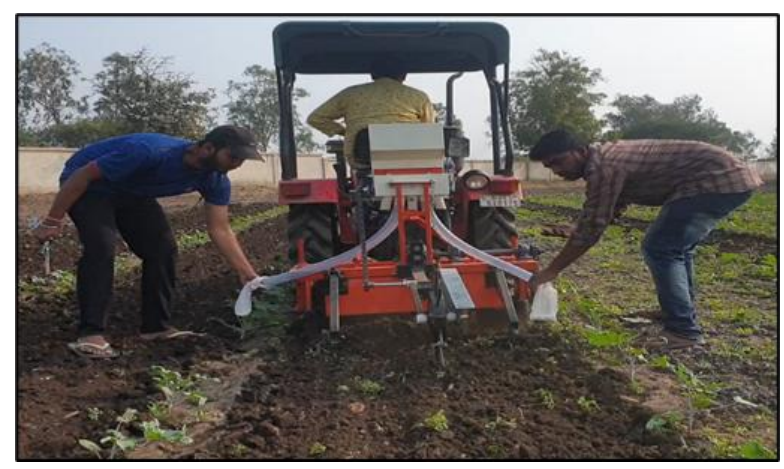

Plate.2 Field view of rotary weeder cum fertilizer drill

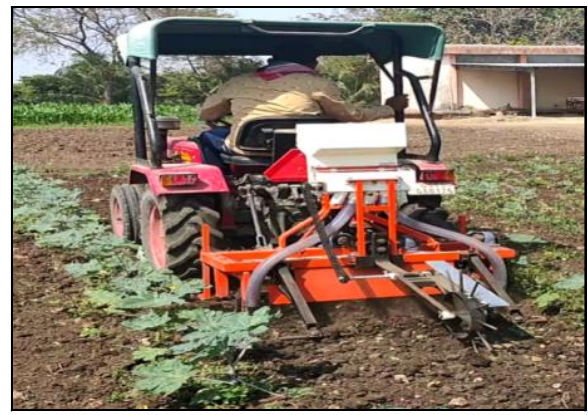

Field efficiency observed at first weeding operation was greater than that of second weeding operation at all the forward speeds during performance evaluation.

\section{Effect of forward speed on plant damage}

Plant damage obtained during both the operations increased by increasing the forward speed from $1.8-2.0 \mathrm{kmh}^{-1}$ to $3.0-3.2$ $\mathrm{kmh}^{-1}$. The results obtained for plant damage in first weeding are statistically nonsignificant. Plant damage was almost same in less grown crop in the field at the time of first weeding. The results obtained for plant damage in second weeding are statistically highly significant because of more plant damage at higher speeds.

Plant damage observed at second weeding operation was more on comparing with the plant damage observed at first weeding

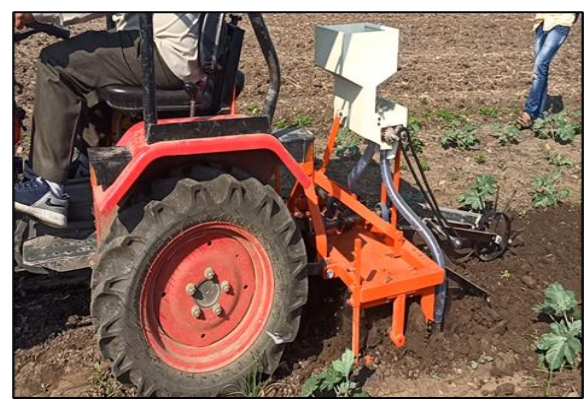

operation at all the speeds. This was because of more growth and spread of plants in the field during second weeding operation.

\section{Effect of forward speed on weeding efficiency}

Weeding efficiency obtained during both the operations decreased by increasing the forward speed from $1.8-2.0 \mathrm{~km} \mathrm{~h}^{-1}$ to $3.0-3.2$ $\mathrm{kmh}^{-1}$. The observations obtained for Weeding efficiency at the time of first weeding and second weeding were statistically highly significant because by varying the forward speed of operation the Weeding efficiency also varied widely in the field during performance evaluation.

Weeding efficiency observed at first weeding operation was more on comparing with the weeding efficiency observed at second weeding operation at all the speeds. It was 
because of more number of weeds per unit area of test plot before weeding operation at the time of first weeding operation on comparing with that of the second weeding operation.

\section{Fuel consumption}

Fuel consumption obtained during both the operations increased by increasing the forward speed from $1.8-2.0 \mathrm{kmh}^{-1}$ to $3.0-3.2$ $\mathrm{km} \mathrm{h}^{-1}$.At the time of first weeding operation the fuel consumption observed at 1.8-2.0 $\mathrm{kmh}^{-1}, 2.5-2.7 \mathrm{kmh}^{-1}$ and $3.0-3.2 \mathrm{kmh}^{-1}$ speeds was $1.30,1.93$ and $2.54 \mathrm{l} \mathrm{h}^{-1}$ respectively. During second weeding operation the fuel consumption observed at $1.8-2.0 \mathrm{kmh}^{-1}, 2.5$ $2.7 \mathrm{kmh}^{-1}$ and $3.0-3.2 \mathrm{kmh}^{-1}$ speeds was 1.03 , 1.44 and $2.14 \mathrm{hah}^{-1}$ respectively. Fuel consumption observed at first weeding operation was more on comparison with the fuel consumption observed at second weeding operation at all the speeds.

\section{Operational energy for mini tractor operated rotary weeder cum fertilizer drill}

The energy spent for weeding operation at 1.8-2.0 $\mathrm{kmh}^{-1}$ speed during performance evaluation was $E_{f}=47.78 \times 1.3=62.12 \mathrm{MJh}^{-1}$.

In conclusion the highest effective field capacity of developed rotary weeder cum fertilizer drill was found as $304 \times 10^{-3} \mathrm{hah}^{-1}$ at the forward speed of $3.0-3.2 \mathrm{kmh}^{-1}$. The highest field efficiency of developed machine was obtained as $86 \%$ at forward speed of 1.8$2.0 \mathrm{kmh}^{-1}$. The highest weeding efficiency of developed machine was obtained as $91.23 \%$ at forward speed of 1.8-2.0 $\mathrm{kmh}^{-1}$.Lowest plant damage of developed machine was obtained as $3.62 \%$ at $1.8-2.0 \mathrm{kmh}^{-1}$. The lowest fuel consumption of developed machine was obtained as $1.031 \mathrm{~h}^{-1}$ at $1.8-2.0$ $\mathrm{kmh}^{-1}$.In fertilizer delivery rates of laboratory calibration and field calibration an average variation of $42.67 \%$ was noticed in the study.

\section{References}

Black, S. R., Sherlock, R. R., Cameron, K. C., Smith, N. P. and Goh, K. M. 1985. Comparison of three field methods for measuring ammonia volatilization from urea granules broadcast on to pasture. European Journal of Soil Science, 36: 271-280.

Hasanuzzaman, M., Ali, M. H., Alam, M. M., Akhtar, M. and Fakhrul, A. K. 2009. Evaluation of pre-emergence herbicide and hand weeding on the weed control efficiency and performance of transplanted rice. American-Eurasian Journal of Agronomy, 2: 138-143.

IS: 17045. 2018. Rotary tiller (rotavator)tractor driven-test procedure, and recommendations on selected performance characteristics. Indian Standards Institution, New Delhi.

IS: 2720-2. 1973. Methods of test for soils, Part II Determination of water content. Indian Standards Institution, New Delhi.

IS: 6316. 1993. Sowing equipment seed cum fertilizer drill. Indian Standards Institution, New Delhi.

Kepner, R. A., Bainer, R. and Barger, E. L. 2005. Principles of Farm Machinery. Ch. 5. CBS Publishing Company, New Delhi, India

Punmia, B. C., Jain, A. K. and Jain, A. K. 2009. Soil Mechanics and Foundations. $16^{\text {th }}$ Edition. Laxmi Publications limited. New Delhi.

Rathod, R. K., Munde, P. A. and Nadre, R. G. 2010. Performance evaluation of tractor drawn inter-raw rotary weeder. International Journal of Agricultural Engineering, 3(1): 161-166.

Stewart, W.M., Dibb, D. W., Johnstone, A.E. and Smyth, T.J. 2005. The Contribution of Commercial Fertilizer Nutrients to Food Production. Agronomy Journal, 19: 1-6.

Vala, V. S., Kathiria, R. K. and Bheda, A. K. 2019. Performance evaluation of mini 
tractor operated rotary weeder. International Journal of Chemical Studies, 7(4): 1124-1127.

Umar, B. 2003. Comparison of manual and manual-cum-mechanical energy uses in groundnut production in a semi-arid environment. Agricultural Engineering International: the CIGR Journal of Scientific Research and Development, 3(3):1-11.

\section{How to cite this article:}

Regatti Venkat, Pramod Mohnot and Dharmendra. 2020. Performance Evaluation of Mini Tractor Operated Rotary Weeder Cum Fertilizer Drill. Int.J.Curr.Microbiol.App.Sci. 9(09): 2962-2974. doi: https://doi.org/10.20546/ijcmas.2020.909.365 